\title{
Screening of Rice (Oryza sativa L.) Genotypes against Grain Discoloration Disease
}

\author{
B. Pampana Gouda ${ }^{1 *}$, T. Narendrappa ${ }^{1}$, B.S. Chethana ${ }^{2}$ and C.A. Deepak ${ }^{2}$ \\ ${ }^{1}$ KrishiVigyan Kendra, Haradanahally Farm, Chamarajanagara-571127, University of \\ Agricultural Science, GKVK, Bengaluru, India \\ ${ }^{2}$ Department of Plant Pathology, University of Agricultural Science, GKVK, Bengaluru, India \\ *Corresponding author
}

\section{A B S T R A C T}

\section{Keywords}

Genotype, Screen,

Resistance,

Susceptibility

Article Info

Accepted:

12 June 2019

Available Online:

10 July 2019
Two years, kharif 2017 and 2018, screening of rice genotypes against grain discoloration under field conditions in Yalandur taluk, Chamarajanagara district revealed that five genotypes viz., viz., BR-2655, Jaya, KCP-1, Rajamudi and Ratnachudi were found moderately resistant. Out of thirty-eight rice genotypes screened, none of the them were found immune or resistant but twenty-one genotypes showed moderate susceptibility and twelve genotypes were susceptibility, The identified moderately resistant genotypes could be used in the disease resistant breeding programme as grain discoloration is considered one of the most important threats to paddy cultivation in Kabini, Kaveri, Thunga, Bhadra, Hilly upland and Coastal areas.

\section{Introduction}

Rice (Oryza sativa L.) is the most important crop of the world both in terms of area $(433.38 \mathrm{~m} \mathrm{ha})$ and production $(481.54 \mathrm{~m} \mathrm{t})$ (Anon., 2016). One out of every three people depends on rice for more than half of their daily diet. Rice is most important staple food in Asia, where 60 per cent world population lives and accounts between $35-60$ per cent of the caloric intake of three billion Asians. In India rice is grown in $43.86 \mathrm{~m} \mathrm{ha}$, the production level was $104.80 \mathrm{mt}$ and the productivity of $2404 \mathrm{~kg} / \mathrm{ha}$ (Anon., 2016). In Karnataka, rice is also extensively cultivated both in kharif and rabi seasons. Total area under rice in Karnataka is 1.42 mha with a production of $3.6 \mathrm{mt}$ accounting for a productivity of $2.62 \mathrm{t}$ per ha (Anon., 2016). This low productivity is attributed due to abiotic and biotic stresses leading to heavy crop losses. Rice crop is prone to attack by several diseases to a much larger extent than any other cereal crops. Rice crop suffers from many diseases like blast, sheath blight, sheath rot, bacterial blight, false smut, grain discoloration, udabatta and tungro. Throughout the world these diseases have drawn much attention and consequently, these diseases have been intensively studied. However, other diseases on which sufficient stress in not yet devoted are generally 
considered as "minor disease". But for the past 5-10 years such diseases problems have come in to light due to heavy crop losses mainly in costal tracts of India, consisting the states namely Andhra Pradesh, Tamil Nadu, Karnataka, West Bengal, Odisha and parts of Bihar.

Grain discoloration was considered to be a minor disease and is now receiving more attention in tropical rice growing areas. The disease is distributed throughout Asia, Africa and America. It is a complex disease due to infection by pathogens on the glume, kernals or both. In Karnataka, it is considered as one of the most important threats to paddy cultivation in Kabini, Kaveri, Thunga, Bhadra, Tungabhadra Hilly upland and Coastal areas. Its intensity varies according to seasons and localities factors such as lodging, frequent rain, high relative humidity and cloudy weather, prevailing particularly from booting to maturity influence the development of grain discoloration.

The main cause of grain discoloration is due to various pathogens, especially species of fungi viz., Curvularia, Drechslera, Sarocladium, Fusarium etc. (Bag, 2007; Sachin and Agarwal, 1995). Grain discoloration results in seedling mortality and reduction in germination and seedling vigour (Bag, 2007), causing significant yield loss. Thus, the pathogens causing grain discoloration have direct influence on both quantity and quality of seeds. Discoloration results in poor quality of grain or seed and an important degrading factor. In such seeds disorders may indicate the presence of seed borne pathogen (Padmanabhan, 1974). In the present context, the development variety looks like an apt choice in the crop improvement programme and is an integral part of Integrated Disease Management (IDM) programmes. Further, it will go a long way in avoiding fungicidal toxicity likely to occur due to chemical spray.

\section{Materials and Methods}

Thirty-eight rice genotypes were collected from Zonal Agricultural Research Station, V.C. Farm, Mandya for screening rice genotypes against grain discoloration. The experiments were conducted in the farmer's field of Yalandur taluk, Chamarajanagara district during kharif 2017 and 2018. The experiment was laid out in Randomized Black Design with two replications in a plot size of $3 \mathrm{~m}^{2}$ and spacing of $20 \times 10 \mathrm{~cm}$. Fertilizers applied at the rate of 100:50:50 kg N, $\mathrm{P}_{2} \mathrm{O}_{5}$, $\mathrm{K}_{2} \mathrm{O} /$ ha. $\mathrm{N}$ and $\mathrm{P}_{2} \mathrm{O}_{5}$ were applied in the form of urea and single super phosphate and potash in the form of muriate of potash. At maturity five ear-heads from each entry were collected and threshed grains were assessed for percentage discoloration by counting the number of healthy and discoloured grains with in the sample.The per cent discoloration was calculated by using the following formulae:

$\begin{aligned} & \% \text { Discoloured grains } \\ & \text { (number based) }\end{aligned}=\frac{\text { Number of discoloured grains }}{\text { Total number of grains }} \times 100$

Later, based on 0 to 9 disease rating scale, the rice genotypes were grouped in to immune, resistant, moderately resistant, moderately susceptible, susceptible and highly susceptible (Anon., 2013) (Table 1).

\section{Results and Discussion}

A total of thirty-eight rice genotypes of short, medium and long duration varieties/ hybrid were screened against grain discoloration during Kharif2017 and 2018 in the farmer's 
field of Yalandur taluk, Chamarajanagara district. The data is presented in the (Table 2 and Fig. 1a - 1c) revealed that, during the Kharif season of 2017, the lowest of 4.80 per cent discoloration was noticed in Ratnachudi and the highest of 48 per cent in Jyoti (Table 2 and Fig. 1a). Similarly, in Kharif 2018, the lowest of 4.85 per cent discoloration was noticed in KCP-1 and the highest of 49 per cent in Mandya Vijaya (Table 2 and Fig. 1b). The average of two seasons indicated that discoloration varied from 4.75 (Jaya) to 47.75 (Mandya Vijaya) per cent (Table 2 and Fig. 1c). The present results are in agreement with Negiand Das (2003).

Out of thirty eight genotypes evaluated, none was found to be immune and resistant against grain discoloration. However, five genotypes viz., BR-2655, Jaya, KCP-1, Rajamudi, and Ratnachudi were found moderately resistant and twenty one genotypes viz., Rasi, KMP153, IR-64, Mandya sona-2, Raksha, KMP128, Jaya X ASD, MTU-1010, IR38064,CTH-1, MSN-100, KMP-200,, GVT-7,
GVT-4, KRH-4, MTU-1001, Tellahamsa, MSN-99, KMP-149, Jyoti X BR-2655 and HR-12, twelve genotypes were susceptible viz., KMP-201, KMP-175, BPT-5204, Jyoti, Basumati-270, JGL-1798, MS-1, Gangavatisona-VCF, Mandya Vijaya, Thanu, RNR-58048, CTH-3 showed moderate susceptibility reaction and none of the genotypes showed highly susceptible reaction and which are represented in (Table 3). The present results are in agreement with findings of Saifulla (1993), Bhimanagouda (2012) Divya (2015) and Varshashikhara (2018).

These conditions also increased the duration of flower opening which predisposed the crop to grain discoloration. The identified moderate resistant genotypes be recommended for cultivation in endemic areas and may be used as source of resistant in the breeding programme in crop improvement. This helps to solve the problem of loss due to this disease and also to avoid the chemical protection/ pollution.

Table.1 Scale description for scoring grain discoloration disease of rice

\begin{tabular}{|c|c|c|}
\hline Disease Score (0-9) & Description & Response \\
\hline $\mathbf{0}$ & No symptom of discoloration & Immune \\
\hline $\mathbf{1}$ & Less than $1 \%$ discoloration & Resistant \\
\hline $\mathbf{5}$ & 1 to $5 \%$ discoloration & Moderately Susceptible \\
\hline $\mathbf{7}$ & 6 to $25 \%$ discoloration & Susceptible \\
\hline $\mathbf{9}$ & 26 to $50 \%$ discoloration & Highly Susceptible \\
\hline
\end{tabular}


Table.2 Screening of short, medium and long duration varieties and hybrid against rice grain discoloration during Kharif 2017-8 and 2018-19 at Chamarajanagara

\begin{tabular}{|c|c|c|c|}
\hline Treatments & \multicolumn{3}{|c|}{ Per cent discoloration } \\
\hline Variety & Kharif 2017 & Kharif2018 & Pooled \\
\hline $\mathbf{T}_{1}$.Rasi & $9.08(17.50)$ & $5.08(12.94)$ & $7.08(15.39) *$ \\
\hline$T_{2} \cdot$ KMP-153 & $5.00(12.92)$ & $8.00(16.31)$ & $6.5(14.72)$ \\
\hline$T_{3}$. IR-64 & $21.00(27.25)$ & $19.50(26.19)$ & $20.25(26.74)$ \\
\hline $\mathrm{T}_{4} \cdot$ Mandya sona- 2 & $16.00(23.56)$ & $18.00(25.07)$ & $17.00(24.32)$ \\
\hline$T_{5-}$ Raksha & $14.50(22.25)$ & $11.50(19.77)$ & $13.00(21.09)$ \\
\hline$T_{6} \cdot$ KMP-201 & $35.00(36.26)$ & $29.00(32.57)$ & $32.00(34.44)$ \\
\hline$T_{7} \cdot$ KMP-128 & $16.80(24.16)$ & $12.60(20.74)$ & $14.70(22.50)$ \\
\hline $\mathrm{T}_{8} \cdot \mathrm{KMP}-175$ & $36.0036 .87)$ & $31.60(34.18)$ & $33.80(35.55)$ \\
\hline $\mathrm{T}_{9 .}$ BR-2655 & $4.50(12.18)$ & $5.00(12.86)$ & $4.75(12.52)$ \\
\hline $\mathbf{T}_{10 \text { - Jaya X ASD }}$ & $8.00(16.31)$ & $7.00(15.26)$ & $7.50(15.84)$ \\
\hline$T_{11}$.MTU -1010 & $21.66(27.73)$ & $18.00(25.07)$ & $19.83(26.44)$ \\
\hline$T_{12 . B P T-5204}$ & $42.14(40.47)$ & $39.40(38.88)$ & $40.77(39.67)$ \\
\hline $\mathbf{T}_{13}$ Jyoti & $48.00(43.85)$ & $45.00(42.18)$ & $46.50(42.99)$ \\
\hline $\mathrm{T}_{14}$ Basumati-270 & $41.50(40.10)$ & $39.00(38.64)$ & $40.25(39.37)$ \\
\hline$T_{15}$ IR-38064 & $19.00(25.81)$ & $23.00(28.64)$ & $21.00(27.25)$ \\
\hline T16 -Jyoti X BR-2655 & $18.00(25.10)$ & $24.00(29.31)$ & $21.00(20.51)$ \\
\hline $\mathbf{T}_{17} . \mathrm{CTH}-1$ & $9.75(18.16)$ & $14.80(22.58)$ & $12.27(28.82)$ \\
\hline$T_{18}-$ HR-12 & $24.53(29.67)$ & $22.00(27.95)$ & $23.26(24.71)$ \\
\hline$T_{19}$. MSN100 & $16.00(23.57)$ & $19.00(25.81)$ & $17.50(21.08)$ \\
\hline $\mathbf{T}_{20}-\mathrm{KMP}-200$ & $12.00(20.20)$ & $14.00(21.92)$ & $13.00(30.63)$ \\
\hline $\mathrm{T}_{21}$ - CTH-3 & $24.00(29.33)$ & $28.00(31.93)$ & $26.00(29.36)$ \\
\hline$T_{22-\text { GVT-7 }}$ & $20.55(26.93)$ & $27.58(31.66)$ & $24.06(23.54)$ \\
\hline $\mathrm{T}_{23}$ - GVT-4 & $14.00(21.92)$ & $18.00(25.07)$ & $16.00(36.33)$ \\
\hline $\mathrm{T}_{24 \text { - JGL-1798 }}$ & $31.80(34.32)$ & $38.4(38.29)$ & $35.10(27.22)$ \\
\hline $\mathbf{T}_{25}$. KRH-4 & $18.00(25.07)$ & $24.00(29.31)$ & $21.00(31.07)$ \\
\hline $\mathrm{T}_{26}-\mathrm{MS}-1$ & $25.88(30.56)$ & $27.50(31.61)$ & $26.69(12.65)$ \\
\hline $\mathbf{T}_{27}$ Jaya & $4.80(12.60)$ & $4.88(12.70)$ & $4.84(33.82)$ \\
\hline$T_{28-G a n g a v a t i s o n a-V C F}$ & $34.00(35.66)$ & $27.00(31.29)$ & $31.00(43.71)$ \\
\hline $\mathbf{T}_{29}$. Mandyavijaya & $46.50(42.99)$ & $49.00(44.43)$ & $47.75(12.75)$ \\
\hline $\mathrm{T}_{30}-\mathrm{KCP}-1$ & $5.00(12.86)$ & $4.85(12.67)$ & $4.92(20.90)$ \\
\hline$T_{31}$-MTU-1001 & $9.00(17.36)$ & $17.50(24.68)$ & $12.75(28.98)$ \\
\hline $\mathbf{T}_{32 \_ \text {Tellahamsa }}$ & $19.00(25.81)$ & $28.00(31.93)$ & $23.50(12.89)$ \\
\hline $\mathbf{T}_{33}$ Rajamudi & $5.08(13.01)$ & $4.88(12.70)$ & $4.98(12.89)$ \\
\hline $\mathbf{T}_{34-\text { Thanu }}$ & $30.00(33.20)$ & $35.50(36.56)$ & $32.75(34.90)$ \\
\hline $\mathbf{T}_{35}$ _Ratnachudi & $4.80(12.59)$ & $4.90(12.71)$ & $4.85(12.65)$ \\
\hline $\mathrm{T}_{36}-\mathrm{RNR}-58048$ & $24.00(29.31)$ & $29.00(32.57)$ & $26.50(30.95)$ \\
\hline $\mathbf{T}_{37}$. MSN-99 & $12.00(20.20)$ & $10.00(18.35)$ & $11.00(19.30)$ \\
\hline 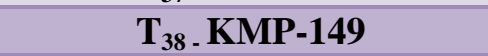 & $10.80(19.15)$ & $9.90(18.25)$ & $10.35(18.71)$ \\
\hline S.Em +_ & 1.30 & 1.40 & 1.32 \\
\hline C.V. & 7.32 & 7.61 & 7.22 \\
\hline C.D. @5\% & 3.77 & 4.02 & 3.78 \\
\hline
\end{tabular}

*(Figures in parenthesis are arc sine transformed values) 
Table.3 Reaction of rice genotypes against rice grain discoloration

\begin{tabular}{|c|c|c|c|}
\hline $\begin{array}{c}\text { Disease } \\
\text { rating scale }\end{array}$ & Response & $\begin{array}{l}\text { No. of } \\
\text { entries }\end{array}$ & Name of varieties / Hybrid varieties/ Germplasm \\
\hline $\mathbf{0}$ & Immune & Nil & Nil \\
\hline 1 & Resistant & Nil & Nil \\
\hline 3 & Moderately Resistant & 5 & BR-2655, Jaya, KCP-1, Rajamudi, and Ratnachudi \\
\hline 5 & Moderately susceptible & 21 & $\begin{array}{l}\text { Rasi, KMP-153, IR-64, Mandya sona-2, Raksha, KMP- } \\
\text { 128, Jaya X ASD, MTU-1010, IR-38064,CTH-1, } \\
\text { MSN-100, KMP-200,, GVT-7, GVT-4, KRH-4, MTU- } \\
\text { 1001, Tellahamsa, MSN-99, KMP-149, Jyoti X BR- } \\
\text { 2655, HR-12 }\end{array}$ \\
\hline 7 & Susceptible & 12 & $\begin{array}{l}\text { KMP-201, KMP-175, BPT-5204, Jyoti, } \\
\text { Basumati-270, JGL-1798, MS-1, Gangavatisona-VCF, } \\
\text { Mandyavijaya, Thanu, RNR-58048, CTH-3 }\end{array}$ \\
\hline 9 & Highly susceptible & Nil & Nil \\
\hline
\end{tabular}

Fig.1a Screening of rice varieties/ hybrids against grain discoloration during Kharif 2017

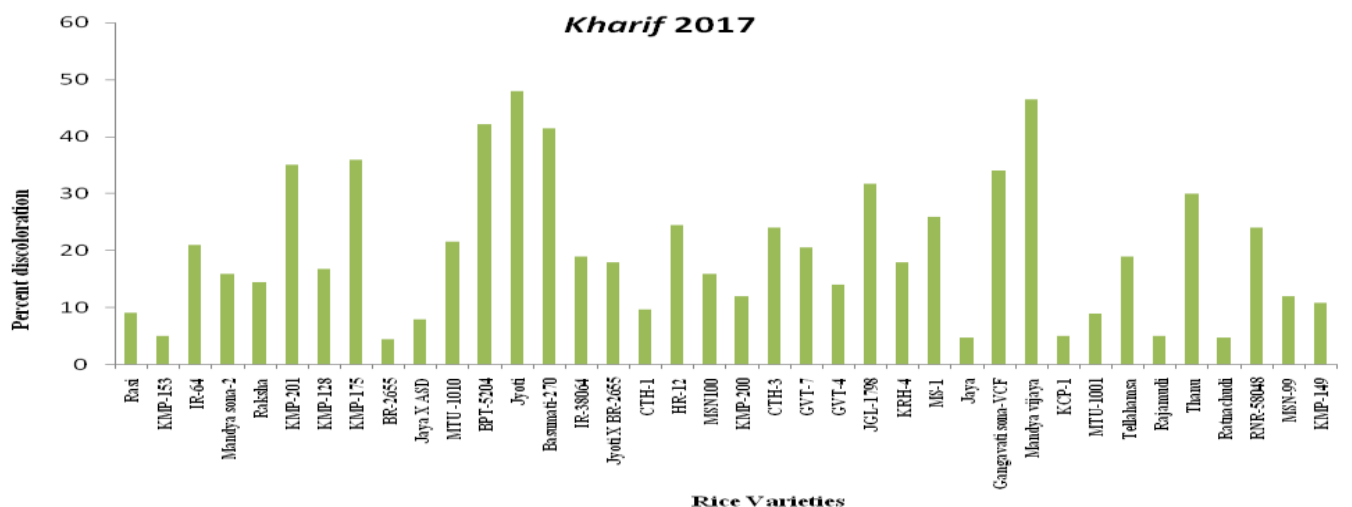

Fig.1b Screening of rice varieties / hybrids against grain discoloration during Kharif 2018

Kharif 2018

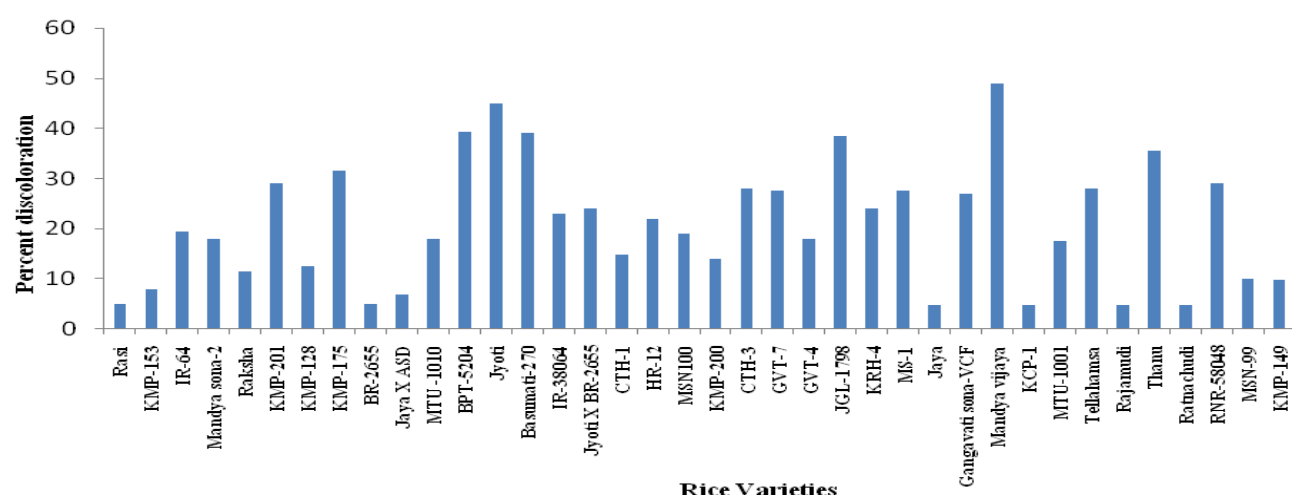


Fig.1c Screening of rice varieties / hybrids against grain discoloration during Kharif 2017and kharif 2018 (Average)

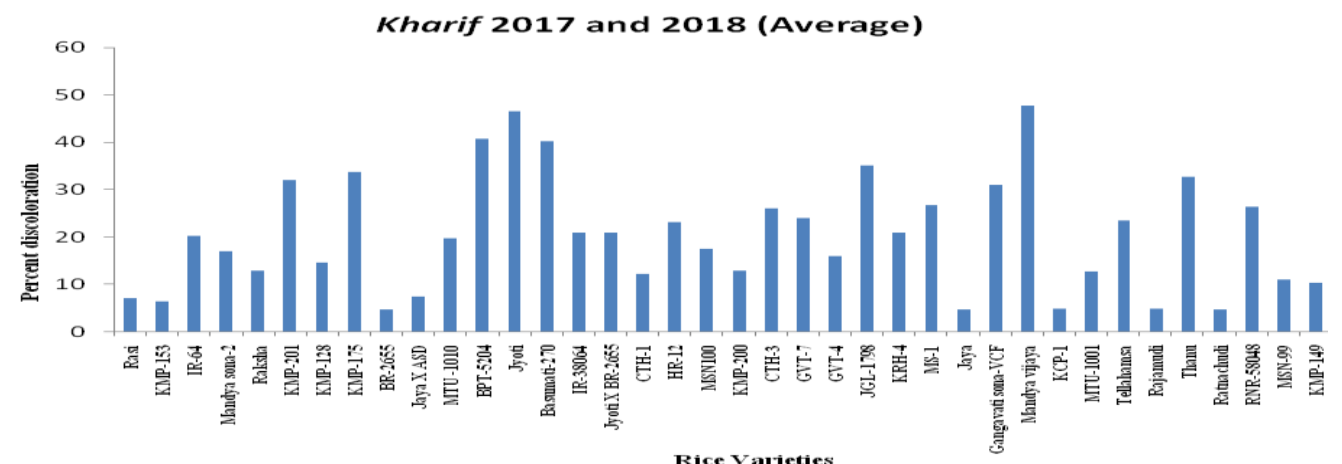

\section{Acknowledgements}

Facilities were provided by Sri. Lokesh belongs to Y.K. Mole village in Yalandur taluk of Chamarajanagara district.

\section{References}

Anonymous, 2013. Standard evaluation system of rice. Indian Rice Research Institute, Philippines. $\mathrm{p} 14$.

Anonymous, 2016. Area, production and productivity of rice in India. Department of agriculture and cooperation and farmer welfare. Аппи. Rep., 3.

Bag, M.K. 2007. Mycoflora causing grain discoloration of rice and its effect on some yield components. In National Symposium on Microbial diversity and seed health, $B C K V$ kalyani West Bengal, p: 2 .

Bhimanagouda, 2012. Management of grain discoloration in rice (Oryzae sativa L.). M. Sc. Thesis, Univ. Agril. Sci., Raichur, India, pp: 67-69.

Dash, A.N. and Avadesh Narain, 1988. Detection of grain discoloration fungal organism of rice and production of disease free seeds. Indian J. Mycol.Pl. Path., 18: 24-30.

Divya, M., 2015. Effect of grain discoloration complex disease on rice seed quality and its management, M. Sc. Thesis, Acharya N.G. Ranga Agril. Univ., Hyderabad, India. pp: 76-78.

Duraiswamy, V.S. and Mariappan, V., 1983. Rice grain discoloration. In: International Rice Research Newsletter.8: 9-10.

Negi, H. and Das, B., 2003, Screening of rice varieties against seed discoloration. Indian Phytopath., 56: 460-461.

Padmanabhan, S. Y., 1974. Control of rice disease in India. Indian Phytopath., 27: 21-28.

Sachin, I.P. and Agarwal, V. K., 1995, Seed discolouration of rice: location of inoculums and influence on nutritional value. Indian Phytopath., 48: 14-20.

Saifulla, M., 1993. Cause and consequence of rice grain discoloration rice. $M . S c$. Thesis, Univ. Mys. Karnataka, India. Pp. 76-77.

Varsha, A., Shekhar, 2018. Studies of grain discoloration in rice. M. Sc. Thesis, Central. Agril.Uni., Bihar, India.

\section{How to cite this article:}

Pampana Gouda, B., T. Narendrappa, B.S. Chethana and Deepak, C.A. 2019. Screening of Rice (Oryza sativa L.) Genotypes against Grain Discoloration Disease. Int.J.Curr.Microbiol.App.Sci. 8(07): 1572-1577. doi: https://doi.org/10.20546/ijcmas.2019.807.187 